\title{
CCI. THE NON-PROTEIN-NITROGEN OF PULSES.
}

\section{PARTITIONING OF THE NITROGEN AND A DETER- MINATION OF THE ESSENTIAL AMINO-ACIDS.}

\author{
BY KAMALA BHAGVAT AND MOTNAHALLI SREENIVASAYA. \\ From the Department of Biochemistry, Indian Institute of Science, Bangalore.
}

(Received 10 May 1936.)

IN a previous communication [1935] attention was drawn to the presence of an easily assimilable non-protein nitrogenous fraction occurring in the pulses to the extent of $10-55 \%$ of the total nitrogen and consisting mostly of the simpler polypeptides. The present study relates to an investigation of the amino-acid make-up of the fraction from the three well-known pulses, Phaseolus aconitifolius, Cicer arietinium and Phaseolus mungo.

\section{EXPERIMENTAL.}

Preliminary trials with $P$. aconitifolius showed that $0.5 \%$ acetic acid was the best solvent, yielding the maximum amount of the non-protein-nitrogen. It was found that a $5 \%$ solution of sodium chloride, whilst extracting the globulins and albumins of the seed, does not effectively dissolve out the non-protein-nitrogen; further, the sodium chloride which persists in the non-protein fraction after the removal of proteins by heat coagulation or acid precipitation cannot be easily eliminated. $0.5 \%$ acetic acid, on the other hand, is not only an efficient solvent for the extraction of the non-protein-nitrogen but can be easily distilled off. It has the further advantage of effecting a coagulation of the globulins during the process of extraction itself.

With a view to determining the percentage of the non-protein-nitrogen (N.P.N.) present in the seed meal, the material (10 g.) was repeatedly (3-5 times) extracted with $100 \mathrm{ml}$. portions of dilute acetic acid in the cold at $0^{\circ}$ to eliminate the possibility of proteoclastic action. Successive extracts obtained by centrifuging the mash were kept separately, warmed up to $60^{\circ}$ to coagulate any albumins that might be present, treated with finely disintegrated Seitz asbestos, filtered and the resulting clear filtrate made up to a known volume, an aliquot of which was employed for a determination of the total nitrogen (T.N.). The clear filtrates were found to yield no precipitate or any opalescence on the addition of trichloroacetic acid, showing thereby that all the proteins had been eliminated. In the case of two pulses, $C$. arietinium and $P$. mungo, filtrations of the later extractions became increasingly difficult and yielded turbid filtrates, owing to the simultaneous extraction of increasing amounts of starch whose presence could be detected by the iodine test.

It will beobserved from Table I that $P$. aconitifolius has a non-protein-nitrogen content which is about thrice that of $C$. arietinium and about four times that of $P$. mungo. The first extraction removes $54-68 \%$ of the N.P.N. present in the seed whilst the yield and purity of the subsequent extracts are low, owing to the extraction of increasing concentrations of carbohydrates whose elimination is 


\section{Table I.}

$\begin{array}{lc}\text { T.N. as } \% & \\ \text { on the wt. } & \% \text { of } \\ \text { of moisture- N.P.N.on } \\ \text { free seed } & \text { the T.N. } \\ 3 \cdot 85 & 34.85 \\ 3 \cdot 50 & 11 \cdot 63 \\ 3 \cdot 74 & 8.86\end{array}$

$\begin{array}{ccccc}\overbrace{1}^{\circ} \text { of } & \text { N.P.X. obtained at each of the extractions } \\ 62.62 & 21 \cdot 88 & 3 & 4 & 5 \\ 68 \cdot 01 & 16 \cdot 55 & 8 \cdot 42 & 4 \cdot 32 & 2 \cdot 75 \\ 54 \cdot 63 & 22 \cdot 69 & 22 \cdot 69(?) & - & -\end{array}$

extremely difficult and whose presence seriously interferes with the analysis of the N.P.N. In our present study, therefore, we have confined our attention to the investigation of the first extract, for obtaining a large quantity of which the following procedure was adopted.

The seed meal $\left(1 \mathrm{~kg}\right.$.) was extracted for 24 hours at $0^{\circ}$ with 10 litres of $0.5 \%$ acetic acid. The extract after filtration was warmed to $60^{\circ}$, treated with asbestos and again filtered, a clear proteinfree filtrate being thus obtained. The filtrate was concentrated at $45-50^{\circ}$ under reduced pressure to about $500 \mathrm{ml}$., and was then preserved in the ice-chest for subsequent experiments.

A partitioning of the nitrogen by the method of Van Slyke as modified by Damodaran [1931] so as to include the dicarboxylic acid-nitrogen, and an independent estimation of some of the essential amino-acids have been carried out. Arginine was determined by the arginase-urease method of Hunter \& Dauphinee [1930] whilst the colorimetric methods of Folin \& Marenzi [1929] were adopted with minor modifications for the estimation of tyrosine, tryptophan and cystine. During the estimation of tryptophan, the precipitate of mercury-tryptophan complex was decomposed by $\mathrm{H}_{2} \mathrm{~S}$ yielding a light-coloured filtrate which was satisfactory for the colorimetric estimation. In the cystine estimation the precipitation of the mercury compound was carried out at $p \mathbf{H} 4 \cdot 6$, at which the cystine was quantitatively precipitated as revealed by preliminary experiments with known additions of cystine to the experimental hydrolysate. The mercury compound was suspended in dilute $\mathrm{H}_{2} \mathrm{SO}_{4}$ solution and was decomposed by $\mathrm{H}_{2} \mathrm{~S}$. HgS was removed by filtration and the excess of $\mathrm{H}_{2} \mathrm{~S}$ from the filtrate eliminated by passing in a current of $\mathrm{CO}_{2}$. For the estimation of tyrosine, no special modification in procedure was found to be necessary. Tyrosine and tryptophan were determined on $5 \mathrm{ml}$. of the non-protein-nitrogen concentrate, which were hydrolysed with $5 \mathrm{ml}$. of a $20 \%$ alkali for 18 hours on a boiling waterbath, whilst for cystine determination, $10 \mathrm{ml}$. of the material were treated with a sufficient amount of sulphuric acid so that the resulting concentration of the acid in the mixture was $4 \%$. The hydrolysis was allowed to proceed for 3 hours in a metal-bath maintained at $110^{\circ}$. For Van Slyke analysis, however, the hydrolysis was carried out under the same conditions of temperature, time and acid concentration except for the fact that hydrochloric in place of the sulphuric acid was employed. Preliminary trials showed that under these conditions a complete fission of the peptide linkages had occurred with the formation of the minimum amount of humin.

Table II. Van Slyke partitioning of the nitrogen as percentages of the total.

\begin{tabular}{|c|c|c|c|c|c|c|c|c|}
\hline $\begin{array}{l}\text { Form of } \\
\text { nitrogen }\end{array}$ & Melanin & Amide & $\begin{array}{l}\text { Dicarbo- } \\
\text { xylic }\end{array}$ & $\begin{array}{l}\text { Basic } \\
\text { amino }\end{array}$ & $\begin{array}{l}\text { Basic } \\
\text { non- } \\
\text { amino }\end{array}$ & $\begin{array}{l}\text { Non- } \\
\text { basic } \\
\text { amino }\end{array}$ & $\begin{array}{l}\text { Non- } \\
\text { basic } \\
\text { non- } \\
\text { amino }\end{array}$ & Total \\
\hline $\begin{array}{l}\text { P.aconitifolius } \\
\text { C. arietinium } \\
\text { P. mungo }\end{array}$ & $\begin{array}{l}\mathbf{1} \cdot \mathbf{2 4} \\
\mathbf{2} \cdot \mathbf{3 4} \\
\mathbf{2 \cdot 3 7}\end{array}$ & $\begin{array}{l}5 \cdot 54 \\
6 \cdot 11 \\
3 \cdot 41\end{array}$ & $\begin{array}{l}23 \cdot 72 \\
13 \cdot 06 \\
16 \cdot 16\end{array}$ & $\begin{array}{l}20 \cdot 56 \\
15 \cdot 22 \\
11 \cdot 21\end{array}$ & $\begin{array}{l}24 \cdot 98 \\
44 \cdot 29 \\
32 \cdot 46\end{array}$ & $\begin{array}{l}25 \cdot 76 \\
19 \cdot 31 \\
19 \cdot 95\end{array}$ & $\begin{array}{r}0.51 \\
0 \cdot 04 \\
16 \cdot 52\end{array}$ & $\begin{array}{l}102 \cdot 31 \\
100 \cdot 39 \\
102 \cdot 10\end{array}$ \\
\hline
\end{tabular}


A study of the above results (Table II) reveals that the N.P.N. fraction of aconite bean has a higher percentage of dicarboxylic acid nitrogen than either of the other two fractions, whilst $C$. arietinium contains the maximum amount of the basic nitrogen. The proline-hydroxyproline content of $P$. mungo appears to be exceptionally high as revealed by the non-amino-nitrogen in the non-basic fraction.

Table III. Essential amino-acids as percentages of total nitrogen.

\begin{tabular}{|c|c|c|c|c|c|}
\hline & $\begin{array}{c}\text { Arginine } \\
\text { (Van Slyke) }\end{array}$ & $\begin{array}{l}\text { Arginine } \\
\text { (enzyme) }\end{array}$ & Tyrosine & Tryptophan & Cystine \\
\hline P. aconitifolius & $12 \cdot 71$ & $11 \cdot 85$ & 0.84 & 0.42 & $C \cdot 22$ \\
\hline C. arietinium & $45 \cdot 48$ & $22 \cdot 92$ & $0 \cdot 60$ & $0 \cdot 50$ & $1 \cdot 13$ \\
\hline P. mungo & 34.59 & $16 \cdot 30$ & 0.78 & $1 \cdot 15$ & $3 \cdot 39$ \\
\hline
\end{tabular}

Table III shows that whilst in the case of $P$. aconitifolius there is a fair agreement between the arginine values obtained by the Van Slyke and enzyme methods, there is a great discrepancy between similar pairs of values for the other two pulses, the values by the enzyme method being about half those by the Van Slyke method. This discrepancy points to the existence of bases other than arginine which are capable of yielding ammonia during alkali hydrolysis and which appear to possess no free amino-group capable of reacting with nitrous acid, as revealed by the high values for non-amino-nitrogen (Table II) in the basic fraction. Further work to characterise these bases is now in progress.

The percentage of tyrosine in the non-protein-nitrogen fraction is very much lower than the tyrosine content of globulins associated with the respective seeds, as given by Niyogi et al. [1932]. The tryptophan content in general follows the same order as obtains in the globulins, whilst the cystine content of the fraction from $P$. mungo is very much higher than the cystine content of the globulins of the seed as reported by Niyogi et al. [1932].

\section{SUMMARY.}

1. The non-protein-nitrogen fractions of the three pulses, $P$. aconitifolius, $C$. arietinium and $P$. mungo, have been extracted by dilute acetic acid and concentrates prepared for analysis. The nitrogen of the fraction has been partitioned by the method of Van Slyke as modified by Damodaran to include dicarboxylic acid-nitrogen.

2. An independent determination of the essential amino-acids, tyrosine, tryptophan, cystine and arginine by the arginase-urease method has been carried out. The results strongly point to the existence of a new base other than arginine.

\section{REFERENCES.}

Bhagvat \& Sreenivasaya (1935). Biochem. J. 29, 909.

Damodaran (1931). Biochem. J. 25, 2123.

Folin \& Marenzi (1929). J. biol. Chem. 83, 89, 103.

Hunter \& Dauphinee (1930). J. biol. Chem. 85, 627.

Niyogi, Narayana \& Desai (1932). Indian J. med. Res. 19, 1041. 